\title{
Report (1966-1970) of the Subcommittee on Numerical Taxonomy to the International Committee on Nomenclature of Bacteria
}

\author{
13 A ugust 1970
}

Mexico City, Mexico

The Subcommittee sponsored the Second International Conference on Microbial Classification in September 1968, at Luhacovice, Czechoslovakia, in collaboration with the Czechoslovak Collection of Microorganisms.

Some years ago the Subcommittee invited V. B. D. Skerman to consider what would be the most useful form of survey of the methods used to examine bacteria. Skerman prepared over the last few years an extensive set of abstracts of published methods. These were published in 1969 under the title of Abstracts of Microbiological Methods. The Subcommittee expressed its warm thanks to Skerman for this endeavor, which will be of great value to all workers in systematic bacteriology.

Members of the Subcommittee collaborated with the Pseudomonas Working Party of the Society for General Microbiology upon the statistical analysis of testing methods with a view to obtaining experience on better standardization and reliability of tests used in systematic bacteriology. A report of the Working Party is expected to be ready soon for publication. Members of the Subcommittee have also been investigating the effect on numerical taxonomies of errors introduced by the poor reproducibility of certain tests: while it has been found that most methods are sufficiently reliable to give relatively little error in the taxa produced, the Subcommittee noted that guidelines for minimum reliability need to be worked out.

Members of the Subcommittee also collaborated with the American Society for Microbiology in producing a manual entitled Methods for Numerical Taxonomy (W. R. Lockhart and J. Liston, ed., 1970, published by the Society).

The Subcommittee examined with interest a report by M. Rogosa, M. I. Krichevsky, and R. R. Colwell, Method for Coding Data on Microbial Strains for Computers, containing an outline of a system for computer storage of data for microbiology. This will be published in the April issue of International Journal of Systematic Bacteriology. It is further hoped that additional work along these lines will be undertaken, leading to the establishment of appropriate data banks.

The Subcommittee considered its future activities and decided that the following required further work and study: establishment of data banks; automated testing methods; statistical validity of clusters; methods for distinguishing closely-allied clusters; and standards for molecular biological methods.

The Subcommittee intends to undertake the production of several documents. Suggested topics are: (i) recommendations on preferred statistical methods for numerical taxonomic studies; (ii) evaluation of molecular biological methods (DNA pairing and GC ratios) with recommendations where appropriate; (iii) lists of institutions where computer facilities are available for numerical taxonomy; (iv) information on current work on computer methods of identification.

The Subcommittee would welcome collaboration with other taxonomic subcommittees of the ICNB in investigating test standardization and would be glad to give advice on numerical methods, if requested.

V. B. D. Skerman retired as Chairman and L. G. Silvestri and P. H. A. Sneath as Secretaries. H. G. Gyllenberg was elected Chairman and R. R. Colwell as Secretary.

The present membership of the Subcommittee is as follows: H. G. Gyllenberg (Chairman), Helsinki, Finland; R. R. Colwell (Secretary), Washington, D.C., USA; J. DeLey, Gent, Belgium; O. Lysenko, Prague, Czechoslovakia; L. G. Silvestri, Milan, Italy; V. B. D. Skerman, Brisbane, Queensland, Australia; and P. H. A. Sneath, Leicester, England.

R. R. Colwell, Secretary H. G. Gyllenberg, Chairman 